\title{
SPECIFICATION OF BIM FOR PROCUREMENT OF WIRING
}

\author{
Filip Vincour*1, Petr Matějka ${ }^{2}$ \\ ${ }^{1}$ Skanska, Krizikova 682/34a, 18600 Prague, Czech Republic \\ ${ }^{2}$ CTU in Prague, Thákurova 7, Prague, 166 29, Czech Republic, petr.matejka@fsv.cvut.cz
}

\begin{abstract}
The paper deals problematic of create level of development matrix a use Information model for wiring. In first part is shown creation matrix and its form with individual elements for high - voltage wiring. The second part describes the individual part of the matrix and the reason for the assignment of information. Further, this section is described by the participants, most affected by creation wiring project, and who has just matrix help. Third part is about application matrix to the real practice and the issue of the introduction of the use of information modeling.
\end{abstract}

\section{Keywords}

BIM; wiring; LOD matrix; Information model; Specification information

\section{JEL Classification}

L23 Organization of Production

DOI: https://doi.org/10.14311/bit.2016.01.01

Editorial information: journal Business \& IT, ISSN 2570-7434, CreativeCommons license (c) (i) published by CTU in Prague, 2016, http://bit.fsv.cvut.cz/ 


\section{Introduction}

In this paper is explained Level of development matrix for wiring, which should help in creating an information model. First part is about their creation and general form. In this part are shown elements and each level of matrix. There is also outlined when and who should be the model to add information and edit model to the final form. Second part is about individual elements of matrix, their specification information. Third part of this paper is about application this matrix and its use in practice.

\section{Methodology}

In order to create a matrix and assign specific information for individual elements, it was necessary to get acquainted with the problems of wiring and information model. Publications relating Level of development for wiring is not much yet. Many information for creation was obtained through interviews with professionals.

\section{Results}

\section{Formation LOD matrix}

The Level of Development matrix was created for high - voltage wiring for specific Czech conditions. In Czech, Level of detail = Level of geometry + Level of information. The matrix includes individual components wiring as lights, sockets, switches, switchboard and electrical wiring. In the first row of the matrix are displayed levels of development and in first column are displayed individual components. The individual levels of development are formed so as to be covered by the construction phase, which are design phase, phase of realization and operational phase. Level of detail specification is necessary for whole construction process $[1,2,3]$.

Level 1 is time, when electric designer and investor should have to fix on the basic element of wiring (lights, sockets, switches) also their location and quantity. Necessary information for elements in this phase are only their quantity and location. Level of detail in this phase is very easy. Level 1 is as Level of development 100 in accordance AIA 202. This level goes to design phase. Next level 2 is design phase too. Design phase is period, when information model is created appropriate to Level 2. On this level there should be fixed lights, sockets, switches in information model to the finally form. Information model in this phase is work electric designer and all elements should be fixed in according to applicable standards. Information on this level should serve for maker high - voltage wiring. All assigned information is show in the research. Information model on this level should be serve as documentation for building permit. Level 2 is as Level of development 300 in accordance AIA 202. At this phase are information about the elements most important for investor, but if he wanted visualization, electric designer must create more level of detail. Last phase, when we adjust information model and added information is operational phase. In this phase is electric designer and maker completes information model level 3. 


\section{Specification elements of LOD matrix}

Matrix is divided on individual components high - voltage wiring, because every one of them needed little different specifications.

\section{Specification Electrical wiring}

This part high - voltage wiring is someone of the most important for detection clashes with other professions as water system, gas system and air - conditioning system. For this reason, is important, that electric designer correctly design this part and added specification as length of cable, placement cable and cable tray. All this information should be added to information model during level 2 and should be done to the time, when starts phase realization building. Information as length, placement are important for contractor wiring, that they could do price offer on their works.

\section{Specification for lights, sockets and switches}

The lights are important elements and from this reason is put emphatic it. Information are added to the information model, so could be shared across life cycle of the building. With the lights are significantly interconnected switches and thus are some information interconnected. Specific information electric elements are added to information model gradually as the project is created. First information adds electric designer and this information is primarily intended for investor and makers wiring. Information needed for makers are displayed in matrix on Level 2. Makers should use this information for creation bids on high - voltage wiring. After building, makers added final information about installed elements. Some of the specific information are information about manufacture, price, serial number... All this information is saved in information model and every partner could export what you need. Information about elements should be used as database for Facility Management, because often after construction are created supporting database. These databases assist in maintenance and repair management. In this issue we may encounter the term Construction Operations Building Information Exchange (COBie). This concept deals about exchange information between the contractor and the future operator so he could use in the operational phase. [4]

Important specific information for wiring on Level 2:

- Electric distribution

- Length

- Location

- Material and type of cable

- Lights

- Quantity

- Luminosity, Luminous flux, Light intensity

- Power

- Cover

- Location

- Material

- Type

- Standards

- Colours

- Switches

- Circuit number

- Quantity

- Colours 
- Location

- Sockets

- Quantity

- Location

- Cover, Voltage, Current

- Switchboards

- Description

- Location

Information added on Level 3:

- Electric distribution

- Real length

- Real location

- Quantity of assistant material

- Lights

- Manufacture

- Type

- Serial number

- Material characteristic

- Contact on the responsible person of the revision and installation

- Price

- Sockets

- Manufacture

- Real quantity

- Contact on the responsible person of the revision and installation

- Switches

- Manufacture

- Real quantity

- Contact on the responsible person of the revision and installation

- Switchboard

- Manufacture

- Description and size

- Contact on the responsible person of the revision and installation

\section{Summary of practical applications}

Level of development matrix shows level of detail and level of information during construction stages. For high - voltage wiring is more important level of information, expect for electrical wiring, where is need level of detail for detection clashes at the design phase. Application matrix was performed in Revit, where it was shown the possibility of inserting and exporting information. Today we are at a stage when the information model not used, because its use and creation is costly. Great response when explaining the contractors raised the possibility of clashes detection, because its big problem in today's construction. Inserted information in the matrix may find its use as part of standards and BIM execution plans. To be an information model used need to be created standards and BIM execution plans, where will be written when it has to carry out and who's done. Level of development matrix could be serve as guide for designers and contractor. 


\section{Conclusion and discussion}

This paper described creation level of development matrix and their used for information model. There have been introduced elements of wiring and the importance of information and level of detail. Paper shows options use for practice. Use information model with additional information and relevant levels of rendering, can help with project management, save time and finance related with clash and other extra work. However, it is necessary to ensure proper coordination between stakeholders, that everyone knew his place and his function. The big problem is the financial aspect, the use of the information model is quite expensive and the Czech construction industry for a while integrating it lasts.

\section{Acknowledgement}

This work was supported by the Grant Agency of the Czech Technical University in Prague, grant SGS15/132/OHK1/2T/11: Vyhodnocování efektivity výstavbových projektů při použití metodiky BIM.

\section{References}

[1] Hijazi, A. A., \& Omar, H. A. Level of detail specifications, standards and file-format challenges in infrastructure projects for BIM level three. WIT Transactions on the Built Environment, 169, 143-154. doi:10.2495/BIM170141

[2] Stumm, S., Schwan, P., Becker, R., Lublasser, E., Blankenbach, J., Vallée, D., Brell-Cokcan, S. Towards life cycle complete BIM. Paper presented at the ISARC - Proceedings of the 34th International Symposium on Automation and Robotics in Construction, 632-638. https://doi.org/10.22260/ISARC2017/0088

[3] Cassano, M., \& Trani, M. L. LOD standardization for construction site elements. Paper presented at the Procedia Engineering, 196 1057-1064. https://doi.org/10.1016/j.proeng.2017.08.062

[4] BIMinfo. BIMinfo [online]. [cit. 2016-December-02]. Available from: http://www.bimfo.cz/Aktuality/Coje-COBie.aspx 